\title{
Milky Stage Versus Dough Stage of Immature Wheat Grain: Effects on Phytic Acid and Fructan Contents, Antioxidant Activity, Textural Parameters, and Sensory Characteristics of Set-Type Yoghurts
}

Çiğgem Konak Göktepe ${ }^{1^{*}}$

https://orcid.org/0000-0003-4615-1050

Nihat Akın ${ }^{1}$

https://orcid.org/0000-0002-0966-1126

${ }^{1}$ University of Selcuk, Department of Food Engineering, Konya, Turkey.

Editor-in-Chief: Paulo Vitor Farago

Associate Editor: Aline Alberti

Received: 2020.03.13; Accepted: 2020.08.09.

*Correspondence: ckonak@selcuk.edu.tr; Tel.: +90-553-3587866 (C.K.G.)

\section{HIGHLIGHTS}

- Yoghurts were supplemented with milky and dough stage wheat grain flours.

- Total antioxidant capacity was improved by wheat grain flour supplementation.

- Milky stage wheat provided higher fructan content than that of dough stage wheat.

- Fermentation reduced phytic acid levels in yoghurts containing wheat grain flours.

\begin{abstract}
Experimental design was performed by using immature wheat grain (IWG) harvested in two different maturation stages for set-type yoghurt production. IWG was harvested at milky (20 days after anthesis) and dough (30 days after anthesis) stages and was milled. Yoghurt samples were supplemented with milky stage grain flour (MSGF) and dough stage grain flour (DSGF) at 1, 2, and 3\% concentrations except for control. All treatments were evaluated with respect to physicochemical, antioxidative, microbiological, textural, and sensorial aspects throughout the 28 days of storage. Phytic acid content of all samples diminished depending on increasing $\mathrm{pH}$ values over the storage while it was found higher in MSGF fortified yoghurts. The highest fructan content was determined in yoghurt fortified with $3 \%$ MSGF. Antioxidant activity and total phenolic content of yoghurts were improved with IWG fortification. MSGF showed higher antioxidant activity as compared to DSGF. On the other hand, DSGF addition presented better water holding capacity in comparison with MSGF. Likewise, DSGF provided higher firmness and consistency values. Firmness was enhanced with IWG supplementation by reducing syneresis except 1\% MSGF added samples. The addition of IWG was found to slightly increase the growth of yoghurt bacteria. Both DSGF and MSGF had adverse effect on the sensory characteristics of yoghurts with their increasing concentrations. Based on the results of this study, to obtain better textural properties and higher antioxidant activity, IWG in different ripening stages can be tried with half combinations (total 3\%) in yoghurt. Also, sensorial properties can be improved by flavoring agents.
\end{abstract}


Keywords: yoghurt; antioxidant activity; immature wheat grain; total fructan; texture.

\section{INTRODUCTION}

Yoghurt is a most popular fermented product which is produced by fermentation of Streptococcus thermophilus and Lactobacillus delbrueckii ssp. bulgaricus. It is consumed all over the world and has numerous positive effects on human health. Yoghurt has a high nutritional value, beneficial and therapeutic properties. This product is easily digestible and a great source of carbohydrates, fat, protein, vitamins and minerals [1]. For many years, researchers have added many antioxidative, antibacterial, antifungal or texture improving supplements into yoghurt. Some studies have been conducted with the aim of enhancing textural properties and nutritional value in yoghurt by means of adding date fiber and wheat bran [2], pulse [3], hazelnut skins [4] and pineapple fiber [5].

Besides, cereals have been the subject of many yoghurt studies due to the containing dietary fiber and other bioactive compounds [6]. Cereal dietary fibers can present countless beneficial effects through their special non-digestible carbohydrate contents which are known as a function of prebiotics [7]. Fructooligosaccharide (FOS), have been used in the food industry due to their technological properties (e.g., syneresis prevention, development of viscosity and textural properties such as creaminess) and nutritional value (e.g., prebiotic effect and calorie reduction). Fortification of dairy product with FOS have presented several functional properties including substituting sugar and fat, providing structural improvement, foam stabilization and prebiotic effects [8].

FOS are involved in fructans group. Fructans are mixtures of molecules composing of fructose moieties linked to each other by $\beta(2 \rightarrow 1)$ bonds. A glucose molecule is linked to the end of the fructose chain by $\alpha$ $(1 \rightarrow 2)$. Fructan is present in wheat grain in concentrations between 2 and $35 \%$ depending on the maturation stage of wheat grain [9]. The fructan content of wheat grain can be influenced by the FOS amount.

IWG is an important source of fructan and has higher protein and fructan content compared to mature wheat grain [10]. The amount of fructan and antioxidant components in IWG is at the highest intensity during the second and third week after anthesis; afterwards fructan content is quickly reduced [11, 12]. Recently, in many studies IWG was used for some food products due to containing high fiber compound and antioxidant activity such as probiotic bread [11,13], biscuits [14], pasta product [10] and tarhana [15] and successful results were obtained from these researches.

The objective of this study was to evaluate utilization of IWG in set-type yoghurt production in terms of physicochemical, textural, microbiological, sensorial, and antioxidative properties of the yoghurts. In this context, the effect of different ripening stages (milky and dough stages) on the mentioned characteristics of yoghurts was also determined.

\section{MATERIAL AND METHODS}

\section{Materials}

Immature wheat grain flour (IWGF) obtained from the grains of the 'Soylu Durum Wheat', harvested at the milky (moisture: $65.85 \pm 1.20 \%$ crude ash: $2.63 \pm 0.17 \%$; protein: $16.99 \pm 0.37 \%$; phytic acid: $1613.69 \pm 17.11$ $\mathrm{mg} / 100 \mathrm{~g}$; total fructan: $4.37 \mathrm{~g} / 100 \mathrm{~g}$; total phenolic content: $475.07 \pm 2.93 \mu \mathrm{g}$ GAE/g; DPPH (inhibition \%): 27.64 $\pm 1.07 \%$; ABTS ${ }^{\bullet+}: 0.37 \pm 0.04 \mathrm{mM}$ trolox/g) and dough (moisture: $51.5 \pm 2.12 \%$ crude ash: $2.32 \pm 0.01 \%$; protein: $16.05 \pm 0.42 \%$; phytic acid: $1549.09 \pm 4.95 \mathrm{mg} / 100 \mathrm{~g}$; total fructan: $4.37 \mathrm{~g} / 100 \mathrm{~g}$; total phenolic content: $350.39 \pm 12.86 \mu \mathrm{g} \mathrm{GAE} / \mathrm{g}$; DPPH (inhibition \%): 19.37 $\pm 0.42 \%$; ABTS ${ }^{\bullet+}: 0.33 \pm 0.03 \mathrm{mM}$ trolox/g) stages from the Sarıcalar Research and Application Farm of the Faculty of Agriculture at Selcuk University.

IWG samples were dried at room temperature to decrease moisture content below $10 \%$. These samples were milled in a hammer mill equipped with a $1 \mathrm{~mm}$ opening screen (Falling Number-3100 Laboratory Mill, Perten Instruments AB, Huddinge, Sweden) to produce IWG flour (IWGF). IWGF was kept at $4{ }^{\circ} \mathrm{C}$ for further analysis.

Yoghurt samples were prepared from whole raw milk $(12.44 \pm 0.08 \%$ total solid content, $3.85 \pm 0.08 \%$ protein, $0.76 \pm 0.11 \%$ ash, $4.00 \pm 0.14 \%$ fat, $\mathrm{pH}: 6.74 \pm 0.01$ ) obtained from the Faculty of Agriculture at Selcuk University. Total non-fat milk solids (NFMS) of the whole milk were standardized (12\% NFMS) with mediumheated skim milk powder supplied by ENKA Dairy Product, Turkey. The freeze-dried starter cultures ( $S$. thermophilus and L. delbrueckii ssp. bulgaricus) were provided from Chr. Hansen-Peyma (Istanbul, Turkey). 


\section{Yoghurt processing}

Whole milk was standardized in $12 \%$ (wWw) NFMS by using medium-heated skim milk powder. Then, this standardized milk was fortified with MSGF or DSGF at levels of 0 (control), 1, 2 and $3 \%(\mathrm{~W} V$ ) and $0.003 \% \mathrm{k}$ carrageenan (Sigma-Aldrich Chemical Company, Inc., USA; WV) to prevent sedimentation of IWGF except for control sample. The obtained mixture was homogenized with an Ultra Turrax blender (IKA, Merck, Germany) by the time all components dissolved in the milk and then heated at $90{ }^{\circ} \mathrm{C}$ for 10 min by stirring. After pasteurization, it was cooled to $42{ }^{\circ} \mathrm{C}$ and inoculated with a $3 \%(\mathrm{v} / \mathrm{v})$ active yoghurt culture. Inoculated mixtures were incubated at $42{ }^{\circ} \mathrm{C}$ until 4.6-4.7 $\mathrm{pH}$. The yoghurt samples were cooled to room temperature after incubation and stored at $4{ }^{\circ} \mathrm{C}$ for 28 days.

\section{Physicochemical analyses}

The AOAC methods were used to measure total solid (method 990.20), crude ash (method 945.46) and protein (method 991.20) content of the yoghurt samples [16]. Fat content of yoghurt samples were determined according to AOAC 2000.18 [17].

Mineral content of the samples were assessed by the method recommended by Skujins [18]. A Minolta Chroma Meter CR-400 (Minolta, Osaka, Japan) was used for measurements of color. The $L^{*}$, $a^{*}$, and $b^{*}$ values detected were in compliance with the CIE Lab color space system [19].

\section{pH and titratable acidity}

The $\mathrm{pH}$, which was measured with a $\mathrm{pH}$ meter (pH $315 \mathrm{i} / \mathrm{SET}$, WTW, Weilheim, Germany), and titratable acidity of yoghurt samples were determined by using the method of Agil, Gaget [20].

\section{Water holding capacity and syneresis}

To measure the water-holding capacity (WHC), an adapted version of the centrifuge method described by $\mathrm{Ye}$, Ren [21] was used. $10 \mathrm{~g}$ yoghurt samples in tubes were centrifuged at $5000 \mathrm{rpm}$ for $20 \mathrm{~min}$ at $4{ }^{\circ} \mathrm{C}$. The WHC was reported as weight of drained whey per $100 \mathrm{~g}$ yoghurt. Syneresis of set-style yoghurts was determined according to Ye, Ren [21].

\section{Phytic acid analysis and total fructan content}

Phytic acid analyses were done on the 1st, 7th, 14th, 21st, and 28th day of cold storage in accordance with the methods described by Haug and Lantzsch [22]. To extract of phytic acid, samples were treated with a solution of $\mathrm{HCl}(0.2 \mathrm{~N})$ for $2.5 \mathrm{~h}$ at $35^{\circ} \mathrm{C}$ under constant stirring and precipitated with ammonium iron (III) sulfate solution. Phytate phosphorous in the supernatant was quantified as the reduction in absorbance of iron content using 2,2-bipyridine at $519 \mathrm{~nm}$.

Fructan content of samples was determined by HPLC after water extraction and enzymatic hydrolysis using a method described in Prosky and Hoebregs [23]. The concentration of fructan is calculated with the amount of free sugars (glucose and fructose) released from fructan in accordance with AACC 32-31 [24]. The chromatography is performed with Perkin Elmer Series 200 incorporating a Phenomenex Rezex RPM, Monosaccharide $(300 \times 7.8 \mathrm{~mm})$ column. Mobile phases are ultra-pure water. The flow rate is $0.6 \mathrm{~mL} / \mathrm{mn}$ and sugars are detected by refractive index (RI) detector. The column temperature was set to be $80{ }^{\circ} \mathrm{C}$. Sugars were identified in conformity with their retention times to compare with sugar standards. The amount of sugar was calculated in reference to calibration curve of each sugar. Fructan analyses were carried out on the 1st, 14 th, and 28 th day of storage.

\section{Texture profile analysis}

Texture profile analysis (TPA) were implemented on TA-XT2 Texture Analyzer (Stable Micro Systems, Godalming, England) equipped with a $5 \mathrm{~kg}$ compression load cell according to method from Öztürk, Aydın [25]. TPA tests were carried out on set-type yoghurts $(150 \mathrm{~mL})$ in plastic containers $(60 \mathrm{~mm}$ internal diameter and $66 \mathrm{~mm}$ sample height). Textural profile of yoghurt samples was measured with A $35 \mathrm{~mm}$ diameter cylindrical probe moved test speed of $1 \mathrm{~mm} / \mathrm{s}$ through $30 \mathrm{~mm}$ inside the yoghurt samples. On the basis of registered force vs. time curve, the firmness (g), consistency ( $\mathrm{g} \mathrm{sec}$ ), cohesiveness (g), and viscosity index (g sec) values were calculated. 


\section{Antioxidant activity analysis and total phenolic content}

Yoghurt extracts were prepared using the method of Öztürk, Aydın [25]. The antioxidant activity of extracted samples was determined by the DPPH scavenging method described by Brand-Williams, Cuvelier [26] and $\mathrm{ABTS}^{\bullet+}$ radical scavenging capacity conducted by the method of Re, Pellegrını [27]. Total phenolic content (TPC) of yoghurt samples was analyzed according to the method of McCue and Shetty [28].

\section{Microbiological analysis}

Viable numbers of $S$. thermophilus and L. delbrueckii ssp. bulgaricus were monitored during 28 days of refrigerated storage. MRS agar ( $\mathrm{pH} 5.4$, Merck KGaA, Darmstadt, Germany) was used for the selective enumeration of $L$. delbrueckii ssp. bulgaricus and plates were anaerobically incubated at $42{ }^{\circ} \mathrm{C}$ for $72 \mathrm{~h}$. $S$. thermophilus was enumerated using M-17 agar (Merck, pH 7.1 Merck KGaA, Darmstadt, Germany) and plates were aerobically incubated at $37^{\circ} \mathrm{C}$ for $48 \mathrm{~h}$ [29]. Yeast and mold counts were determined using Potato Dextrose Agar after aerobic incubation at $25^{\circ} \mathrm{C}$ for 5 days [30].

\section{Sensory analysis}

Sensory characteristics of the yoghurt samples were performed by nine trained members from Faculty of Agriculture at Selcuk University according to described by Tamime, Barrantes [31] using five-point hedonic scale (1: dislike very much; 5: like very much) for appearance, texture, mouth feel, odour and taste. Sensory analysis was carried out on the 14th day of cold storage.

\section{Statistical analysis}

Data were statistically evaluated via analysis of variance (ANOVA) and the means were compared by Tukey's test at $p<0.05$ using MiniTab 7.1 [32].

\section{RESULTS AND DISCUSSION}

\section{Physicochemical characteristics of yoghurt samples}

Physicochemical characteristics of yoghurt samples are shown in Table 1. The total solid contents in yoghurt samples were determined to be between 15.61 and $17.60 \%$ and total solid contents augmented with increasing concentrations of MSGF and DSGF. Crude ash and protein values of samples were found between $1.02-1.08 \%$ and $5.38-6.58 \%$, respectively. The crude ash and protein contents of yoghurt samples increased significantly $(\mathrm{p}<0.05)$ with the increasing amounts of MSGF and DSGF. The highest crude ash and protein value was determined at yoghurts with 3\% MSGF. MSGF (2.63\%) had higher ash content than DSGF $(2.32 \%)$ because ash content of wheat grain decreases during seed maturation. These results are in agreement with the previous studies of Levent and Bilgiçli [33] and Katagiri, Masuda [34]. Fat content of yoghurt samples ranged from 3.50 to $3.79 \%$. Generally, the fat contents showed a decrease with increasing concentrations of MSGF and DSGF as compared to control yoghurt. On the other hand, no statistically differences were observed between fat values of the samples with MSGF and DSGF. Similarly, several researchers noticed that fiber-enriched yoghurts had less fat content compared with control yoghurts [35, 36].

The highest lightness $\left(\mathrm{L}^{*}\right)$ value was recorded for the control yoghurt while lightness values of all fortified yoghurts decreased significantly $(p<0.05)$ with the increasing enrichment ratio. There were no significant differences $(p>0.05)$ in greenness $\left(a^{*}\right)$ values of yoghurt with MSGF and DSGF. A significant $(p<0.05)$ increase in yellowness ( $\left.b^{*}\right)$ values was observed in yoghurts fortified with MSGF and DSGF. Similarly, Hashim, Khalil [2] reported that greenness and yellowness values of yoghurt samples advanced with increasing concentrations of date fiber used in the formulation. Although there was an increase in the mineral content of all yogurt samples with the addition of MSGF and DSGF in general, the differences in the $\mathrm{Cu}, \mathrm{K}$, $P$ and $Z n$ values of the yoghurt samples were not statistically significant ( $p>0.05)$. Additionally, $\mathrm{Mg}$ values of yoghurt samples improved depending on the increasing ratio of MSGF and DSGF $(p<0.05)$. Furthermore, Mg values of yoghurt samples with DSGF were lower than samples with MSGF. It was determined that the Mg content gradually decreased from milky stage to dough stage during kernel development and maturation (data not shown). 
Table 1. Some physicochemical properties of yoghurts at the 7th day of refrigerated storage.

\begin{tabular}{|c|c|c|c|c|c|c|c|}
\hline \multirow{2}{*}{ 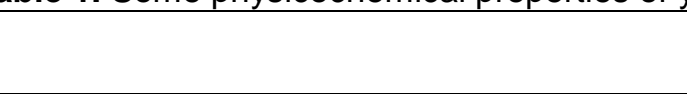 } & \multicolumn{7}{|c|}{ Sample } \\
\hline & Control & 1\% MSGF & 2\% MSGF & $3 \%$ MSGF & 1\% DSGF & 2\% DSGF & $3 \%$ DSGF \\
\hline Total solid matter (\%) & $15.61 \pm 0.28^{c}$ & $16.20 \pm 0.15^{\mathrm{bc}}$ & $16.97 \pm 0.28^{\mathrm{abc}}$ & $17.60 \pm 0.29^{a}$ & $15.96 \pm 0.22^{b c}$ & $17.20 \pm 0.31^{\mathrm{ab}}$ & $17.59 \pm 0.66^{a}$ \\
\hline Crude ash (\%) & $1.02 \pm 0.001^{d}$ & $1.04 \pm 0.00^{\mathrm{cd}}$ & $1.07 \pm 0.00^{\mathrm{ab}}$ & $1.08 \pm 0.00^{a}$ & $1.03 \pm 0.01^{d}$ & $1.04 \pm 0.01^{\mathrm{cd}}$ & $1.05 \pm 0.00^{\mathrm{bc}}$ \\
\hline Protein (\%) & $5.38 \pm 0.01^{c}$ & $5.70 \pm 0.24^{b c}$ & $6.18 \pm 0.12^{\mathrm{ab}}$ & $6.58 \pm 0.12^{a}$ & $5.66 \pm 0.36 \mathrm{bc}$ & $6.02 \pm 0.17^{a b c}$ & $6.26 \pm 0.06^{\mathrm{ab}}$ \\
\hline Fat (\%) & $3.79 \pm 0.10^{a}$ & $3.75 \pm 0.07^{a}$ & $3.68 \pm 0.03^{a b}$ & $3.50 \pm 0.08^{b}$ & $3.72 \pm 0.03^{a b}$ & $3.62 \pm 0.03^{a b}$ & $3.59 \pm 0.01^{\mathrm{ab}}$ \\
\hline \multicolumn{8}{|c|}{ Mineral matter content $(\mathbf{m g} / \mathbf{1 0 0 g})$} \\
\hline $\mathrm{Ca}$ & $145.1 \pm 0.6^{\mathrm{ns}}$ & $142.4 \pm 2.3^{\mathrm{ns}}$ & $137.9 \pm 1.0^{\mathrm{ns}}$ & $128.6 \pm 9.2^{\mathrm{ns}}$ & $140.6 \pm 5.2^{\mathrm{ns}}$ & $137.5 \pm 2.3^{\mathrm{ns}}$ & $134.3 \pm 6.4^{\mathrm{ns}}$ \\
\hline $\mathrm{Cu}$ & $0.03 \pm 0.01^{\mathrm{ns}}$ & $0.05 \pm 0.00^{\mathrm{ns}}$ & $0.06 \pm 0.01^{\mathrm{ns}}$ & $0.04 \pm 0.02^{\text {ns }}$ & $0.03 \pm 0.00^{\mathrm{ns}}$ & $0.04 \pm 0.01^{\mathrm{ns}}$ & $0.06 \pm 0.01^{\mathrm{ns}}$ \\
\hline K & $214.1 \pm 11.4^{\mathrm{ns}}$ & $217.3 \pm 8.0^{\mathrm{ns}}$ & $224.1 \pm 0.8^{\text {ns }}$ & $228.1 \pm 2.5^{\mathrm{ns}}$ & $215.5 \pm 6.1^{\mathrm{ns}}$ & $222.0 \pm 0.1^{\mathrm{ns}}$ & $224.3 \pm 4.2^{n s}$ \\
\hline Mg & $15.99 \pm 0.06^{c}$ & $17.47 \pm 0.21^{\mathrm{abc}}$ & $18.07 \pm 0.12^{\mathrm{ab}}$ & $18.78 \pm 1.08^{a}$ & $16.50 \pm 0.32^{b c}$ & $17.66 \pm 0.24^{a b c}$ & $17.94 \pm 0.04^{a b}$ \\
\hline $\mathbf{P}$ & $165.4 \pm 10.8^{\text {ns }}$ & $167.9 \pm 5.1^{\mathrm{ns}}$ & $169.5 \pm 5.3^{\text {ns }}$ & $177.0 \pm 14.1^{\mathrm{ns}}$ & $165.9 \pm 6.5^{\mathrm{ns}}$ & $173.1 \pm 1.5^{\mathrm{ns}}$ & $175.2 \pm 4.1^{\mathrm{ns}}$ \\
\hline Zn & $0.58 \pm 0.00^{\mathrm{ns}}$ & $0.61 \pm 0.01^{\mathrm{ns}}$ & $0.66 \pm 0.01^{\mathrm{ns}}$ & $0.69 \pm 0.02^{\mathrm{ns}}$ & $0.60 \pm 0.04^{\mathrm{ns}}$ & $0.62 \pm 0.05^{\mathrm{ns}}$ & $0.68 \pm 0.05^{\mathrm{ns}}$ \\
\hline \multicolumn{8}{|l|}{ Color } \\
\hline $\mathbf{L}^{*}$ & $91.63 \pm 0.61^{a}$ & $90.01 \pm 0.24^{b c}$ & $88.76 \pm 0.29^{d}$ & $88.36 \pm 0.21^{d}$ & $90.77 \pm 0.13^{a b}$ & $89.07 \pm 0.34^{\mathrm{cd}}$ & $88.18 \pm 0.13^{d}$ \\
\hline$a^{*}$ & $-2.59 \pm 0.67^{\mathrm{ns}}$ & $-2.56 \pm 0.36^{\mathrm{ns}}$ & $-2.15 \pm 0.41^{\mathrm{ns}}$ & $-2.00 \pm 0.20^{\mathrm{ns}}$ & $-2.49 \pm 0.32^{\mathrm{ns}}$ & $-2.22 \pm 0.17^{\mathrm{ns}}$ & $-2.25 \pm 0.24^{\text {ns }}$ \\
\hline $\mathbf{b}^{*}$ & $6.14 \pm 1.03^{d}$ & $8.92 \pm 0.18^{b c}$ & $10.33 \pm 0.47^{a b}$ & $11.20 \pm 0.45^{a}$ & $8.08 \pm 0.02^{\mathrm{cd}}$ & $9.50 \pm 0.22^{\mathrm{abc}}$ & $10.11 \pm 0.46^{\mathrm{ab}}$ \\
\hline
\end{tabular}

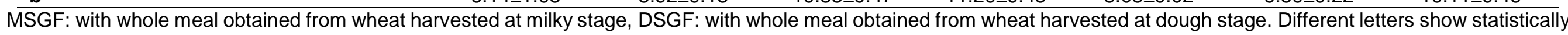
differences $(P<0.05)$. NS: not statistically significant. 

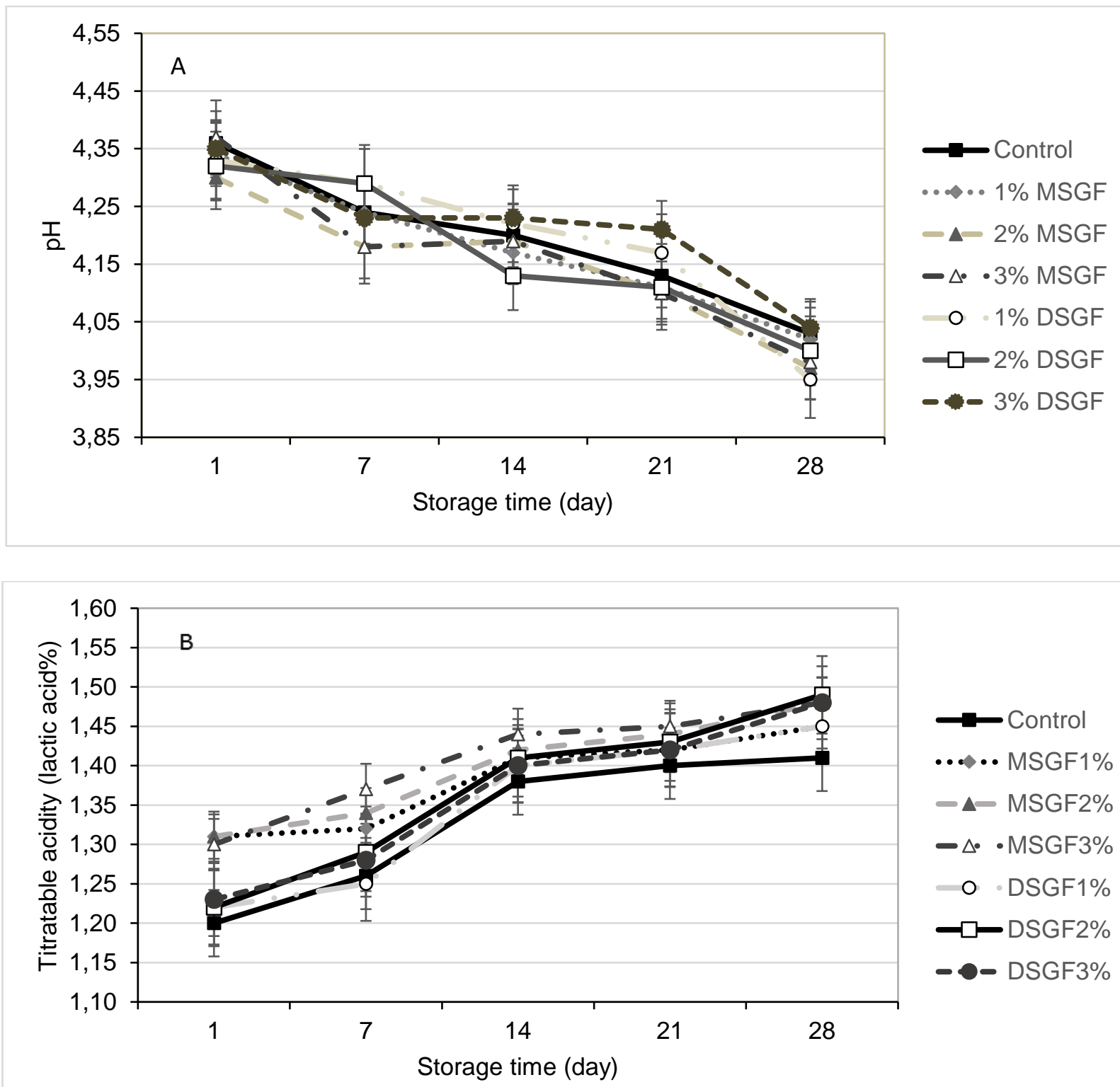

Figure 1. Changes in the $\mathrm{pH}$ and titratable acidity values of yoghurts during the storage time; $\mathrm{A}, \mathrm{pH} ; \mathrm{B}$, Titratable acidity. MSGF: with whole meal obtained from wheat harvested at milky stage, DSGF: with whole meal obtained from wheat harvested at dough stage.

The $\mathrm{pH}$ and titratable acidity values observed during 28 days of refrigerated storage are given in Figure 1. The $\mathrm{pH}$ values of yoghurt samples varied from 3.90 to 4.37 during the storage time. Unsurprisingly, yoghurts with MSGF and DSGF had lower pH values compared with the plain yoghurt. The lowest pH value was detected in yoghurts containing $2 \%$ MSGF. This result could be associated with positive influence of $2 \%$ MSGF on yoghurt bacteria. In parallel with our results, Akalın, Gönç [37] reported that the pH value of the reduced-fat yoghurt enriched with FOS was lower than that of the yoghurt sample without FOS depending upon the effect of FOS on the counts of $S$. thermophilus, L. delbrueckii ssp. bulgaricus and B. animalis. As seen in Figure 1, titratable acidity values were found between $1.20-1.49 \%$ during the storage time. Yoghurt samples with MSGF and DSGF had lower acidity values at the first day of storage, while the higher acidity values showed at the end of the storage. A continuous increase in acidity may be attributed to metabolic activities of lactic acid bacteria in yoghurts [35].

\section{Water holding capacity and syneresis}

WHC of yoghurt samples ranged from $46.18 \%$ to $62.87 \%$ (Table 2). Yoghurts enriched with DSGF had higher WHC than yoghurts with MSGF. The DSGF supplement contained higher starch content than that of 
the MSGF supplement. Starch whose concentration increases during maturation of wheat grain plays a role in water absorption in the food system [38, 39]. The highest WHC was observed in yoghurts enriched with 3\% DSGF. Similarly, Öztürk, Aydın [25] determined that the addition of peeled and unpeeled oleaster flour to yoghurt sample increased WHC of yoghurts. Besides, statistically no significant difference was found between the other enrichment rates in MSGF and DSGF added yoghurts. In all fortified yoghurt samples except to that containing 2\% MSGF no change in WHC were determined throughout the storage period.

Table 2. Water holding capacity and syneresis values of yoghurts during the storage time.

\begin{tabular}{|c|c|c|c|c|c|c|c|}
\hline \multirow{2}{*}{$\begin{array}{c}\text { Storage } \\
\text { times } \\
\text { (day) }\end{array}$} & \multicolumn{7}{|c|}{ Sample } \\
\hline & Control & $1 \%$ MSGF & $2 \%$ MSGF & $3 \%$ MSGF & $1 \%$ DSGF & $2 \%$ DSGF & $3 \%$ DSGF \\
\hline \multicolumn{8}{|c|}{ Water holding capacity (\%) } \\
\hline 1 & $\underset{\mathrm{D}, \mathrm{b}}{47.08 \pm 0.19}$ & $\underset{\substack{4, \mathrm{~ns} \\
46.18 \pm 1.30}}{ }$ & $\underset{\mathrm{b}}{51.67 \pm 0.14 \mathrm{CD}}$ & $\begin{array}{c}55.70 \pm 2.40^{\mathrm{BC}} \\
\mathrm{D}, \mathrm{ns}\end{array}$ & $\underset{\mathrm{C}, \mathrm{ns}}{49.75 \pm 3.18^{\mathrm{AB}}}$ & $\begin{array}{l}57.40 \pm 2.03^{\mathrm{A}} \\
\mathrm{B}, \mathrm{ns}\end{array}$ & $\underset{\mathrm{A}, \mathrm{ns}}{60.64 \pm 0.38}$ \\
\hline 7 & $\begin{array}{c}52.89 \pm 0.89 \\
B, a\end{array}$ & $\underset{B, n s}{51.70 \pm 2.22}$ & $\underset{\mathrm{a}}{54.60 \pm 0.85^{\mathrm{AB}}}$ & $\underset{\mathrm{ns}}{59.72 \pm 1.82^{\mathrm{AB}}}$ & $\underset{n s}{53.88 \pm 3.51^{A B}}$ & $\underset{\mathrm{B}, \mathrm{ns}}{57.65 \pm 3.61^{\mathrm{A}}}$ & $\underset{\mathrm{A}, \mathrm{ns}}{62.87 \pm 1.60}$ \\
\hline 14 & $\begin{array}{c}52.97 \pm 1.70 \\
B, a\end{array}$ & $\begin{array}{c}51.62 \pm 2.24 \\
\mathrm{~B}, \mathrm{~ns}\end{array}$ & $\underset{\mathrm{b}}{54.25 \pm 0.83^{\mathrm{B}, \mathrm{a}}}$ & $\underset{n s}{58.10 \pm 1.88^{A B}}$ & $\underset{\mathrm{s}}{53.95 \pm 3.32^{\mathrm{B}, \mathrm{n}}}$ & $\begin{array}{c}58.87 \pm 0.47^{A} \\
B, n s\end{array}$ & $\underset{A, n s}{62.55 \pm 1.63}$ \\
\hline 21 & $\begin{array}{c}52.27 \pm 0.23 \\
B, a\end{array}$ & $\begin{array}{c}51.08 \pm 1.86 \\
\text { B,ns }\end{array}$ & $\underset{b}{52.89 \pm 0.83^{B, a}}$ & $\underset{n s}{57.17 \pm 2.45^{A B}}$ & $\underset{\mathrm{ns}}{53.92 \pm 3.94^{\mathrm{AB}}}$ & $\begin{array}{c}58.60 \pm 1.65^{\mathrm{A}} \\
\mathrm{B}, \mathrm{ns}\end{array}$ & $\underset{\mathrm{A}, \mathrm{ns}}{62.02 \pm 1.58}$ \\
\hline 28 & $\begin{array}{c}51.35 \pm 0.49 \\
C D, a\end{array}$ & $\underset{\substack{4, \mathrm{~ns} \\
48.67 \pm 0.57}}{ }$ & $\begin{array}{c}52.00 \pm 0.75^{\mathrm{BC}} \\
\mathrm{D}, \mathrm{ab}\end{array}$ & $\underset{\mathrm{C}, \mathrm{ns}}{55.80^{\mathrm{AB}}}$ & $\underset{\mathrm{D}, \mathrm{ns}}{52.37 \pm 1.65^{\mathrm{BC}}}$ & $\underset{B, n s}{58.09 \pm 0.30^{A}}$ & $\underset{A, n s}{61.13 \pm 2.69}$ \\
\hline \multicolumn{8}{|c|}{ Syneresis (\%) } \\
\hline 1 & $\underset{A, n s}{39.36 \pm 0.23}$ & $\underset{\mathrm{A}, \mathrm{ns}}{29.65 \pm 7.96}$ & $\underset{s}{29.05 \pm 8.33^{A, n}}$ & $4.63 \pm 0.00^{\mathrm{B}, \mathrm{e}}$ & $\underset{\mathrm{s}}{26.37 \pm 4.01^{\mathrm{A}, \mathrm{n}}}$ & $\underset{s}{7.90 \pm 0.94^{B, n}}$ & $\underset{\mathrm{c}}{2.32 \pm 0.21^{\mathrm{B}},}$ \\
\hline 7 & $\underset{A, n s}{37.86 \pm 1.72}$ & $\begin{array}{c}31.60 \pm 5.73 \\
A B, n s\end{array}$ & $\underset{n s}{31.28 \pm 0.60^{A B}}$ & $6.30 \pm 0.00^{\mathrm{c}, \mathrm{d}}$ & $\underset{s}{26.01 \pm 4.66^{B, n}}$ & $\begin{array}{c}7.65 \pm 1.23^{C, n} \\
s\end{array}$ & $\underset{c}{3.28 \pm 0.23 c,}$ \\
\hline 14 & $\underset{\mathrm{A}, \mathrm{ns}}{38.42 \pm 1.19}$ & $\begin{array}{c}33.41 \pm 2.09 \\
A B, n s\end{array}$ & $\begin{array}{c}31.37 \pm 1.68 \mathrm{AB} \\
\mathrm{ns}\end{array}$ & $12.21 \pm 0.00^{\mathrm{C}, \mathrm{c}}$ & $\begin{array}{c}30.64 \pm 1.90^{B, n} \\
s\end{array}$ & $\underset{\mathrm{ns}}{12.34 \pm 3.50^{\mathrm{C}} \text {, }}$ & $\underset{b}{6.30 \pm 0.71^{c}}$ \\
\hline 21 & $\underset{A, n s}{38.37 \pm 0.56}$ & $\begin{array}{c}33.87 \pm 1.44 \\
A, n s\end{array}$ & $\underset{\mathrm{s}}{33.43 \pm 3.54^{\mathrm{A}, \mathrm{n}}}$ & $13.84 \pm 0.00^{\mathrm{B}, \mathrm{b}}$ & $\underset{\mathrm{s}}{31.80 \pm 1.78^{\mathrm{A}, \mathrm{n}}}$ & $\underset{\mathrm{ns}}{13.13 \pm 4.62^{\mathrm{B}},}$ & $\frac{6.82 \pm 0.04^{\mathrm{B}},}{\mathrm{ab}}$ \\
\hline 28 & $\underset{A, n s}{39.79 \pm 0.00}$ & $\underset{B, n s}{33.82 \pm 0.00}$ & $\begin{array}{c}34.25 \pm 2.38^{B, n} \\
s\end{array}$ & $15.20 \pm 0.00^{C, a}$ & $\begin{array}{c}34.65 \pm 0.00^{\mathrm{B}, \mathrm{n}} \\
\mathrm{s}\end{array}$ & $\underset{\mathrm{ns}}{17.30 \pm 0.00^{\mathrm{C}} \text {, }}$ & $\begin{array}{c}7.87 \pm 0.00^{\mathrm{D}}, \\
\mathrm{a}\end{array}$ \\
\hline
\end{tabular}

MSGF: with whole meal obtained from wheat harvested at milky stage, DSGF: with whole meal obtained from wheat harvested at dough stage. Statistically differences were showed different letters $(P<0.05)$.

A-EThe significant differences between the samples were expressed in capital letters, ${ }^{\mathrm{a}-\mathrm{e}}$ The significant differences between storage times were expressed in lower case letters.

The syneresis results are shown in Table 2. Generally, a significant $(p<0.05)$ decrease in syneresis of yoghurt samples was observed in parallel with increment in rates of MSGF and DSGF. While the average syneresis of control yoghurt was $38.76 \%$, this value decreased to $10.44 \%$ and $5.32 \%$ in yoghurts enriched with 3\% MSGF and 3\% DSGF, respectively. The microstructure of yoghurt is composed of casein micelles and their clusters. Syneresis susceptibility is closely related to the gaps between casein clusters [40]. The decrease in syneresis depending on the increase of MSGF and DSGF could be explained by filling these gaps in the casein clusters with fructans and starch. This result is in agreement with a findings of CrispínIsidro, Lobato-Calleros [41] who reported that the addition inulin and agave fructans decreased the syneresis of reduced-fat yoghurts. The highest syneresis values for all yoghurt samples were observed on the 28th day of storage which may be attributed to increasing in acidity by activity of the yoghurt starter cultures especially L. delbrueckii ssp. bulgaricus on the progressive storage period $[42,43]$.

\section{Phytic acid values of enriched yoghurts}

The effects of MSGF and DSGF on phytic acid contents are presented in Table 3. The highest phytic acid content $(497.85 \mathrm{mg} / 100 \mathrm{mg})$ was observed in the 3\% MSGF enriched yoghurt sample $(p<0.05)$. It was determined that the amount of phytic acid in the yoghurt samples with MSGF was higher than yoghurt that with DSGF. This situation could be explained that phytic acid content in the MSGF $(1613.69 \mathrm{mg} / 100 \mathrm{~g})$ was higher than the phytic acid found in the DSGF $(1549.09 \mathrm{mg} / 100 \mathrm{~g})$. The present results are consistent with the findings of Levent and Bilgiçli [33] who notified that the amount of phytic acid in the wheat kernel decreased as the ripening period progressed. The phytic acid content of enriched yoghurt samples decreased significantly $(p<0.05)$ with the progressed storage time and the lowest results observed on the 28th day of 
storage. In our study, phytic acid contents of yoghurt samples fortified with MSGF and DSGF decreased during fermentation and storage times in compatible with results of Bilgiçli and İbanoğlu [44] who stated that $\mathrm{pH}$ value of the medium was an important factor that affects phytate degradation and low $\mathrm{pH}$ values increased phytate degradation.

Table 3. Phytic acid values $(\mathrm{mg} / 100 \mathrm{~g})$ of yoghurts during the storage time.

\begin{tabular}{|c|c|c|c|c|c|c|c|}
\hline \multirow{2}{*}{$\begin{array}{c}\text { Storage } \\
\text { times } \\
\text { (day) }\end{array}$} & \multicolumn{7}{|c|}{ Sample } \\
\hline & Control & $1 \%$ MSGF & $2 \%$ MSGF & $3 \%$ MSGF & $1 \%$ DSGF & $2 \%$ DSGF & $3 \%$ DSGF \\
\hline 1 & $\underset{a}{326.8 \pm 0.1^{D}}$ & $\underset{a}{431.5 \pm 6.3^{C}}$ & $\begin{array}{c}480.0 \pm 5.7^{A} \\
B, a\end{array}$ & $497.9 \pm 7.9^{\mathrm{A}, \mathrm{a}}$ & $439.7 \pm 4.1^{\mathrm{C}, \mathrm{a}}$ & $432.6 \pm 3.0^{\mathrm{c}, \mathrm{a}}$ & $475.1 \pm 2.2^{\mathrm{B}, \mathrm{a}}$ \\
\hline 7 & $\underset{b}{305.8 \pm 3.0^{E}}$ & $\underset{\mathrm{b}}{377.6 \pm 4.6^{\mathrm{D}}}$ & $\underset{\mathrm{C}, \mathrm{b}}{414.3 \pm 6.3^{\mathrm{B}}}$ & $463.5 \pm 5.7^{\mathrm{A}, \mathrm{b}}$ & $400.1 \pm 2.8^{\mathrm{C}, \mathrm{b}}$ & $403.2 \pm 6.6^{\mathrm{BC}, \mathrm{b}}$ & $422.4 \pm 7.7^{\mathrm{B}, \mathrm{b}}$ \\
\hline 14 & $\underset{c}{264.2 \pm 3.1^{E}}$ & $\underset{c}{332.3 \pm 4.4^{D}}$ & $\underset{D, c}{361.7 \pm 9.6^{C}}$ & $435.1 \pm 7.9^{\mathrm{A}, \mathrm{b}}$ & $343.9 \pm 9.6^{C D, c}$ & $365.9 \pm 6.2^{\mathrm{BC}, \mathrm{c}}$ & $394.2 \pm 8.5^{\mathrm{B}, \mathrm{c}}$ \\
\hline 21 & $\underset{d}{193.0 \pm 0.4^{D}}$ & $203.7 \pm 6.7^{D}$ & $\underset{\mathrm{C}, \mathrm{d}}{237.1 \pm 7.0^{\mathrm{B}}}$ & $281.1 \pm 7.7^{\mathrm{A}, \mathrm{C}}$ & $203.9 \pm 8.9 \mathrm{D}, \mathrm{d}$ & $218.2 \pm 7.8^{\mathrm{CD}, \mathrm{d}}$ & $259.1 \pm 3.3^{A B, d}$ \\
\hline 28 & $e^{112.3 \pm 3.1 E}$ & $\begin{array}{c}162.6 \pm 7.8^{\mathrm{D}} \\
\mathrm{e}\end{array}$ & $\underset{\substack{182.6 \pm 8.9 C \\
D, e}}{c}$ & $262.5 \pm 8.6^{A, C}$ & $158.8 \pm 4.0^{\mathrm{D}, \mathrm{e}}$ & $195.3 \pm 8.9^{B C, d}$ & $223.0 \pm 7.9 \mathrm{~B}, \mathrm{e}$ \\
\hline
\end{tabular}

MSGF: with whole meal obtained from wheat harvested at milky stage, DSGF: with whole meal obtained from wheat harvested at dough stage. Statistically differences were showed different letters $(P<0.05)$.

A-EThe significant differences between the samples were expressed in capital letters, ${ }^{a-e}$ The significant differences between storage times were expressed in lower case letters.

\section{Total fructan contents}

As shown in Table 4, total fructan content of yoghurt samples ranged from 0.0 to $0.104 \mathrm{~g} / 100 \mathrm{~g}$. The highest fructan content $(p<0.05)$ was determined in the 3\% MSGF sample on the firt day of storage because the MSGF $(4.37 \pm 0.13 \mathrm{~g} / 100 \mathrm{~g})$ had higher fructan content than the DSGF $(3.76 \mathrm{~g} / 100 \mathrm{~g})$. The amount of fructans in wheat kernel is based on their phase of maturity. Paradiso, Cecchini [12] reported that fructans are concentrated at a higher level in the first period of ripening. Their quantity per grain is quickly reduced 23 weeks after anthesis. Although the amount of fructan increased significantly $(p<0.05)$ with the concentration of IWG in all enriched yoghurt samples except control, it showed a decrease on the progressive storage period. The reduction in total fructan contents of the samples might be associated with the metabolic activities of lactic acid bacteria in yoghurts because fructan may promote the growth of specific bacteria as a prebiotic [45]. Similar findings was found by Akalın, Fenderya [46] who reported that FOS stimulating the growth of yoghurt bacteria and bifidobacteria.

Table 4. Total fructan values $(\mathrm{g} / 100 \mathrm{~g})$ of yoghurts during the storage time.

\begin{tabular}{|c|c|c|c|c|c|c|c|}
\hline \multirow{2}{*}{$\begin{array}{c}\text { Storage } \\
\text { times } \\
\text { (day) }\end{array}$} & \multicolumn{7}{|c|}{ Sample } \\
\hline & Control & $1 \%$ MSGF & $2 \%$ MSGF & $3 \%$ MSGF & $1 \%$ DSGF & $2 \%$ DSGF & $3 \%$ DSGF \\
\hline 1 & $\begin{array}{c}0.003 \pm 0.0 \\
01^{\mathrm{D}, \mathrm{a}}\end{array}$ & $\underset{\mathrm{C}, \mathrm{a}}{0.048 \pm 0.009^{\mathrm{B}}}$ & $\underset{\mathrm{B}, \mathrm{a}}{0.071 \pm 0.002}$ & $\begin{array}{c}0.104 \pm 0.00 \\
6^{\mathrm{A}, \mathrm{a}}\end{array}$ & $\underset{\mathrm{C}, \mathrm{a}}{0.030 \pm 0.008}$ & $\underset{\mathrm{C}, \mathrm{a}}{0.048 \pm 0.006^{\mathrm{B}}}$ & $\underset{, a}{0.072 \pm 0.009^{B}}$ \\
\hline 14 & $\begin{array}{l}0.001 \pm 0.0 \\
00^{\mathrm{C}, \mathrm{ab}}\end{array}$ & $\underset{, a b}{0.030 \pm 0.007^{B}}$ & $\underset{A B, b}{0.046 \pm 0.004}$ & $\begin{array}{c}0.055 \pm 0.00 \\
6^{A, b}\end{array}$ & $\underset{\mathrm{C}, \mathrm{ab}}{0.013 \pm 0.001}$ & $\underset{\mathrm{ab}}{0.032 \pm 0.004^{\mathrm{B}}}$ & $\underset{, b}{0.035 \pm 0.001^{B}}$ \\
\hline 28 & $\begin{array}{c}0.000 \pm 0.0 \\
00^{\mathrm{D}, \mathrm{b}}\end{array}$ & $\underset{\mathrm{CD}, \mathrm{b}}{0.004 \pm 0.005^{\mathrm{B}}}$ & $\begin{array}{c}0.019 \pm 0.001 \\
A B, c\end{array}$ & $\begin{array}{c}0.028 \pm 0.00 \\
1^{A, C}\end{array}$ & $\underset{C D, b}{0.002 \pm 0.003}$ & $\begin{array}{c}0.012 \pm 0.008^{A} \\
B C D, b\end{array}$ & $\underset{B C, b}{0.018 \pm 0.003^{A}}$ \\
\hline
\end{tabular}

MSGF: with whole meal obtained from wheat harvested at milky stage, DSGF: with whole meal obtained from wheat harvested at dough stage. Statistically differences were shown different letters $(P<0.05)$.

A-DThe significant differences between the samples were expressed in capital letters, ${ }^{a-c}$ The significant differences between storage times were expressed in lower case letters.

\section{Textural properties}

All textural parameters (firmness, consistency, cohesiveness and viscosity index) of yoghurt samples are shown in Figure 2. The average firmness values of yoghurts ranged between 210.04-535.22 $\mathrm{g}$ during storage. 
Firmness advanced with the increasing total solids content of enriched yoghurt samples as well as interaction between IWG and the milk protein matrix [47]. Besides, a raise in firmness could be related to decreasing $\mathrm{pH}$ values that induced to syneresis [5]. As expected, firmness value was higher in samples with $3 \% \mathrm{MSGF}$ and DSGF. This result was parallel with decreasing syneresis values depending on increasing concentrations of MSGF and DSGF. On the other hand, firmness slightly increased until the 14th day of storage and then decreased towards the end of the storage period. Similar findings of the decreased firmness over the storage were reported by Costa, Frasao [48] who researched the effect of cupuassu pulp on yoghurt texture. Also, Izadi, Nasirpour [49] observed similar trend in yoghurt fortified with phytosterol.

The average consistency values of yoghurts ranged between $5170.64 \mathrm{~g} \mathrm{sec}$ and $11321.02 \mathrm{~g} \mathrm{sec}$. The storage period and enrichment rate were significant $(p<0.05)$ on consistency values of yoghurts. The higher consistency values were determined in yoghurt samples with 3\% DSGF compared with other yoghurt samples at the first day of storage. This result may be expressed by the greater levels of starch in DSGF [50]. The starch binds water and interacts with casein molecules $($ at $<4.6 \mathrm{pH})$ in yoghurt system [35]. Our results corroborate to the findings of do Espírito Santo, Perego [51] who reported that passion fruit peel powder addition in yoghurts increased consistency values. Similarly, Srisuvor, Chinprahast [52] noticed that the use of inulin and polydextrose in low-fat set type yoghurts significantly improved consistency of yoghurts.

Cohesiveness demonstrates the level to which a material can be deformed before it ruptures [53]. Cohesiveness showed a decrease with increasing levels of MSGF and DSGF as compared to plain yoghurt, therefore samples fortified with 3\% MSGF and DSGF had the lowest cohesiveness values throughout the storage. Our result is parallel to the findings of Mohamed, Zayan [54] noted that addition of dried grape pomace of yoghurt at 1,2, and 3\% concentrations reduced cohesiveness, while firmness increased these enrichment ratios. Generally, no differences were observed between cohesiveness values of MSGF and DSGF supplemented yoghurts and cohesiveness values of both of them were found to be lower than control yoghurt. On the other side, cohesiveness values of all samples enhanced at the end of the storage time. An increment in cohesiveness during cold storage was reported in the study of Mousavi, Heshmati [55]. The researchers found that cohesiveness of yoghurt containing flaxseed increased during storage time resulting from flaxseed affected on internal bonds in yoghurt structure. Thus, IWG, which contains a high proportion of fiber, can influence on bond in casein micelles.

As with cohesiveness values, viscosity index of yoghurt samples decreased depending on MSGF and DSGF fortification in comparison to control yoghurt. Moreover, increasing concentration of MSGF and DSGF caused decrease in viscosity index of yoghurts. Kycia, Chlebowska-Śmigiel [56] explained that this could be due to unfinished forming of a casein network during gelation by the presence of nonadsorbing polysaccharide. Besides, compared to the beginning of storage, viscosity index of all yoghurt samples advanced at the end of the storage due to enhanced interaction of IWG with caseins. Similarly, Rudra, Nath [57] stated that addition of inulin in yoghurt caused an increment in viscosity during storage was attributed to stabilization of casein-inulin networks. Yoghurts containing MSGF and DSGF generally showed similar viscosity index, however, the highest viscosity index was observed in yoghurts with 1 and 2\% DSGF on day of 28.

\section{Antioxidant capacity of yoghurt samples}

The results of antioxidant capacity, obtained in the DPPH and ABTS•+ assays, are given in Table 5. Immature wheat grain is a more important source of bioactive phytochemicals with antioxidative attributes, such as $\alpha$-and $y$ tocopherol, vitamin $C, \beta$-carotene, phenolics and flavonoids than mature wheat $[58,59]$. For this reason, as expected, yoghurt samples with 3\% MSGF gave the highest DPPH scavenging capacities with average $4.43 \%$ inhibition. Besides to DPPH results, TEAC values of enriched yoghurt samples also increased significantly $(p<0.05)$ with increasing concentrations of MSGF and DSGF. The yoghurts with MSGF had higher ABTS $\bullet+$ and DPPH scavenging values than yoghurts with DSGF. Similarly, Kim and Kim [58] and Merendino, D'Aquino [60] reported that immature wheat had higher antioxidant capacity than mature wheat. Fortified yoghurts exhibited significantly higher ABTS•+ and DPPH scavenging capacities than their respective controls.

Although the highest antioxidant capacities of the yoghurt samples were detected at the end of the storage time $(p<0.05)$, there were no statistical differences in antioxidant values of the samples in the previous days $(p>0.05)$. The results for increased antioxidant capacity after storage is possibly attributed to activities of lactic acid bacteria during the storage time [61] and the forming of an interaction between polyphenols and milk proteins [62]. 

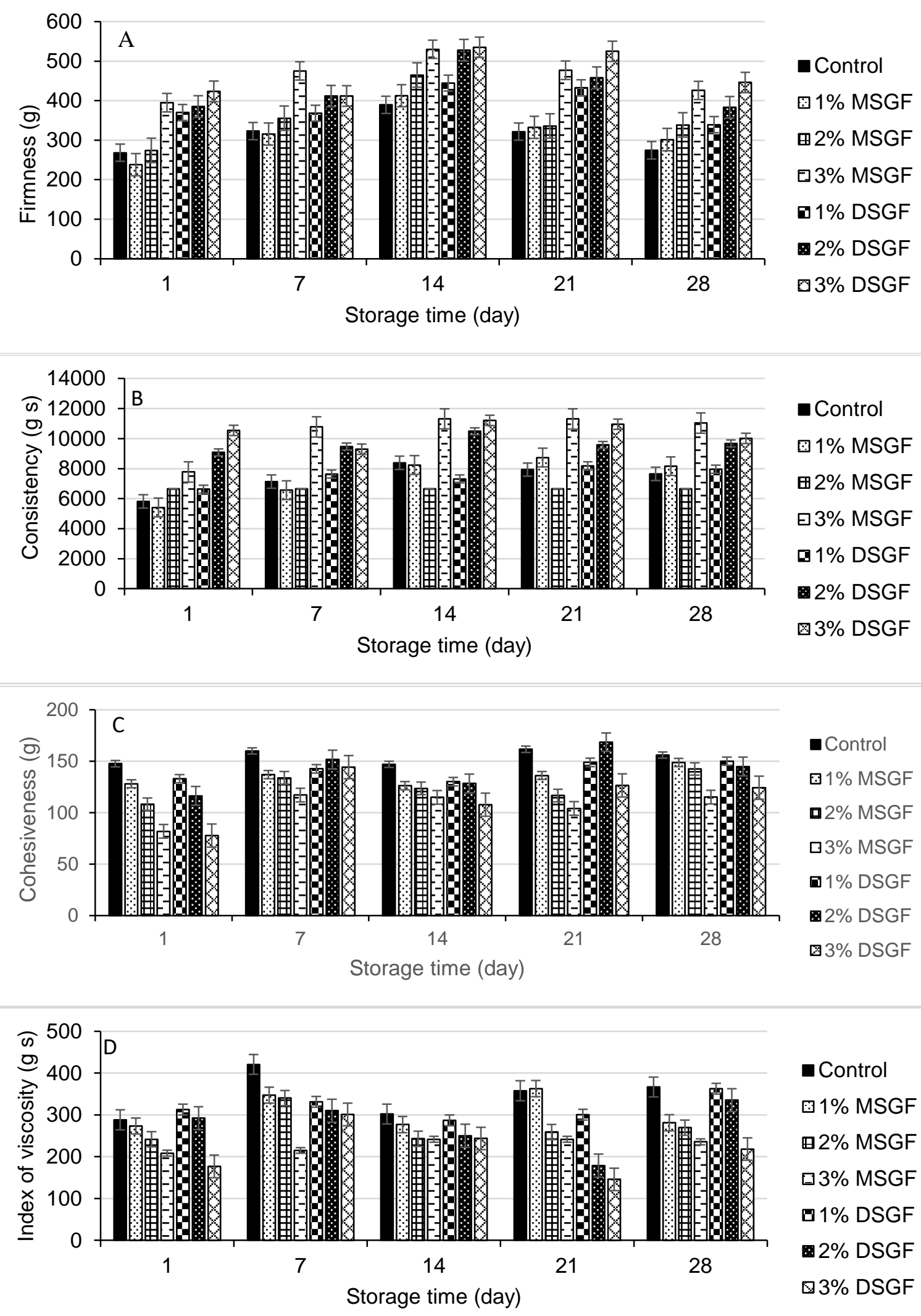

Figure 2. Texture profile of yoghurts during storage time; A, firmness; B, consistency; C, cohesiveness; D, index of viscosity. MSGF: with whole meal obtained from wheat harvested at milky stage, DSGF: with whole meal obtained from wheat harvested at dough stage.

\section{Total phenolic content of yoghurt samples}

The total phenolic contents (TPC) of yoghurt samples are shown in Table 5. TPC content ranged from 64.84 to $96.83 \mu \mathrm{g} \mathrm{GAE} / \mathrm{g}$. The TPC of samples increased significantly $(p<0.05)$ depending on the increasing 
concentration of MSGF and DSGF. The yoghurts containing 3\% of both MSGF and DSGF, had the highest total phenolic content. The highest total phenolic level in the samples was observed on the 28th day of storage. The increase in the TPC of the samples depended on the progressed time during the storage period may be explained by the metabolic activity of yoghurt bacteria.

Table 5. Antioxidant activity and total phenolic content of yoghurt samples.

\begin{tabular}{|c|c|c|c|c|c|c|c|}
\hline \multirow{2}{*}{$\begin{array}{c}\text { Storage } \\
\text { times } \\
\text { (day) }\end{array}$} & \multicolumn{7}{|c|}{ Sample } \\
\hline & Control & $1 \%$ MSGF & $2 \%$ MSGF & $3 \%$ MSGF & $1 \%$ DSGF & $2 \%$ DSGF & $3 \%$ DSGF \\
\hline \multicolumn{8}{|c|}{ DPPH (\% inhibition) } \\
\hline 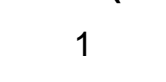 & $2.24 \pm 0.13^{D}$ & $\underset{b}{3.43 \pm 0.21 \mathrm{ABC}}$ & $\underset{B, b}{3.58 \pm 0.21^{A}}$ & $\underset{b}{3.92 \pm 0.23^{\mathrm{A}}}$ & $2.84 \pm 0.20^{\mathrm{CD}, \mathrm{b}}$ & $\underset{\mathrm{D}, \mathrm{b}}{2.86 \pm 0.13^{\mathrm{C}}}$ & $3.18 \pm 0.03^{\mathrm{BC}, \mathrm{c}}$ \\
\hline 7 & $\frac{2.62 \pm 0.27^{B}}{a b}$ & $3.71 \pm 0.15^{\mathrm{A}, \mathrm{ab}}$ & $\begin{array}{l}4.09 \pm 0.21^{\mathrm{A}} \\
\mathrm{ab}\end{array}$ & $\frac{4.21 \pm 0.22^{\mathrm{A}}}{\mathrm{ab}}$ & $\underset{b}{3.26 \pm 0.30^{A B, a}}$ & $\underset{a}{3.88 \pm 0.32^{A}}$ & $3.97 \pm 0.13^{\mathrm{A}, \mathrm{b}}$ \\
\hline 14 & $\underset{a b}{2.68 \pm 0.15^{D}}$ & $\begin{array}{l}3.82 \pm 0.08^{B C, a} \\
b\end{array}$ & $\begin{array}{c}4.46 \pm 0.26^{A} \\
B, a\end{array}$ & $\underset{a b}{4.60 \pm 0.14^{A}}$ & $3.50 \pm 0.04^{\mathrm{C}, \mathrm{ab}}$ & $\underset{\mathrm{B}, \mathrm{a}}{4.23 \pm 0.12^{\mathrm{A}}}$ & $4.68 \pm 0.25^{\mathrm{A}, \mathrm{a}}$ \\
\hline 21 & $\underset{a b}{2.82 \pm 0.03 E}$ & $\begin{array}{l}3.87 \pm 0.02^{C D, a} \\
b\end{array}$ & $\underset{B, a}{4.51 \pm 0.15^{A}}$ & $\underset{B, a b}{4.68 \pm 0.18^{A}}$ & $3.58 \pm 0.02^{\mathrm{D}, \mathrm{a}}$ & $\underset{\mathrm{C}, \mathrm{a}}{4.26 \pm 0.24^{\mathrm{B}}}$ & $4.87 \pm 0.19^{\mathrm{A}, \mathrm{a}}$ \\
\hline 28 & $\underset{a}{3.04 \pm 0.27^{C}}$ & $3.97 \pm 0.10^{\mathrm{B}, \mathrm{a}}$ & $\underset{a}{4.64 \pm 0.16^{\mathrm{A}}}$ & $\frac{4.73 \pm 0.17^{\mathrm{A}}}{\mathrm{a}}$ & $3.79 \pm 0.10^{\mathrm{B}, \mathrm{a}}$ & $\begin{array}{c}4.27 \pm 0.19^{A} \\
B, a\end{array}$ & $4.88 \pm 0.08^{\mathrm{A}, \mathrm{a}}$ \\
\hline \multicolumn{8}{|c|}{ ABTS $^{+}(\mathrm{mM}$ Trolox/g) } \\
\hline 1 & $\underset{\mathrm{B}, \mathrm{b}}{0.130 \pm 0.01}$ & $\underset{, b}{0.152 \pm 0.01^{A B}}$ & $\begin{array}{c}0.147 \pm 0.00 \\
A B, C\end{array}$ & $\underset{\mathrm{A}, \mathrm{b}}{0.171 \pm 0.02}$ & $\underset{, \mathrm{b}}{0.142 \pm 0.01^{\mathrm{AB}}}$ & $\begin{array}{c}0.144 \pm 0.01 \\
A B, b\end{array}$ & $\underset{, c}{0.144 \pm 0.00^{\mathrm{AB}}}$ \\
\hline 7 & $\begin{array}{c}0.132 \pm 0.01 \\
B, b\end{array}$ & $\underset{, a b}{0.167 \pm 0.01 A B}$ & $\begin{array}{c}0.168 \pm 0.01 \\
A B, b c\end{array}$ & $\begin{array}{c}0.190 \pm 0.01 \\
\mathrm{~A}, \mathrm{ab}\end{array}$ & $\underset{, a b}{0.163 \pm 0.00^{A B}}$ & $\begin{array}{c}0.177 \pm 0.01 \\
\mathrm{~A}, \mathrm{a}\end{array}$ & $0.187 \underset{\mathrm{b}}{ \pm 0.01^{\mathrm{A}}}$ \\
\hline 14 & $\begin{array}{c}0.147 \pm 0.01 \\
\mathrm{~B}, \mathrm{~b}\end{array}$ & $\underset{, a b}{0.170 \pm 0.01^{A B}}$ & $\begin{array}{c}0.176 \pm 0.01 \\
A B, b\end{array}$ & $\underset{A, a b}{0.200 \pm 0.01}$ & $\underset{, a b}{0.168 \pm 0.01^{A B}}$ & $\begin{array}{c}0.178 \pm 0.00 \\
A B, a\end{array}$ & $0.194 \underset{b}{0.01^{A}}$ \\
\hline 21 & $\underset{\mathrm{C}, \mathrm{ab}}{0.159 \pm 0.00}$ & $\underset{, \mathrm{ab}}{0.171 \pm 0.00^{\mathrm{BC}}}$ & $\begin{array}{c}0.179 \pm 0.00 \\
B C, b\end{array}$ & $\underset{\mathrm{A}, \mathrm{a}}{0.225 \pm 0.01}$ & $\underset{, a b}{0.176 \pm 0.02^{B C}}$ & $\begin{array}{c}0.178 \pm 0.01 \\
B C, a\end{array}$ & $\underset{, a b}{0.205 \pm 0.01^{A B}}$ \\
\hline 28 & $\underset{B, a}{0.193 \pm 0.01}$ & $\underset{, a}{0.203 \pm 0.02^{A B}}$ & $\begin{array}{c}0.211 \pm 0.01 \\
A B, a\end{array}$ & $\underset{\mathrm{A}, \mathrm{a}}{0.240 \pm 0.01}$ & $0.184 \pm 0.01^{\mathrm{B}, \mathrm{a}}$ & $\begin{array}{c}0.205 \pm 0.01 \\
A B, a\end{array}$ & $\underset{, a}{0.225 \pm 0.01^{A B}}$ \\
\hline \multicolumn{8}{|c|}{ Total phenolic content ( $\mu \mathrm{g}$ GAE/g) } \\
\hline 1 & $\underset{B, n s}{64.84 \pm 1.06}$ & $67.91 \pm 1.98^{\mathrm{B}, \mathrm{b}}$ & $\begin{array}{c}67.90 \pm 0.46 \\
B, n s\end{array}$ & $\underset{A, C}{75.67 \pm 1.79}$ & $68.05 \pm 0.77^{\mathrm{B}, \mathrm{c}}$ & $\begin{array}{c}75.82 \pm 0.87 \\
A, b\end{array}$ & 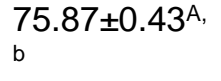 \\
\hline 7 & $\underset{B, n s}{71.99 \pm 1.66}$ & $\underset{b}{73.64 \pm 1.24^{B, a}}$ & $\begin{array}{c}76.54 \pm 6.23 \\
\mathrm{AB}, \mathrm{ns}\end{array}$ & $\underset{A, b}{85.53 \pm 0.07}$ & $73.51 \pm 1.52^{\mathrm{B}, \mathrm{b}}$ & $\begin{array}{c}78.00 \pm 0.16 \\
A B, b\end{array}$ & $\begin{array}{c}79.35 \pm 2.53^{A B} \\
, a b\end{array}$ \\
\hline 14 & $\begin{array}{c}73.30 \pm 2.92 \\
B, n s\end{array}$ & $\underset{, a b}{77.44 \pm 4.27^{A B}}$ & $\begin{array}{c}79.50 \pm 4.48 \\
\mathrm{AB}, \mathrm{ns}\end{array}$ & $\underset{A, b}{87.52 \pm 1.36}$ & $74.69 \pm 1.99 \mathrm{~B}, \mathrm{~b}$ & $\begin{array}{c}78.44 \pm 1.33 \\
A B, b\end{array}$ & $\underset{, a b}{82.84 \pm 2.96^{A B}}$ \\
\hline 21 & $\underset{\mathrm{C}, \mathrm{ns}}{75.02 \pm 1.21}$ & $\underset{, \mathrm{ab}}{77.76 \pm 2.78^{\mathrm{BC}}}$ & $\begin{array}{c}80.24 \pm 2.31 \\
B C, n s\end{array}$ & $\underset{\mathrm{A}, \mathrm{a}}{92.35 \pm 1.31}$ & $\underset{, \mathrm{ab}}{76.56 \pm 0.78^{\mathrm{BC}}}$ & $\underset{B C, b}{79.77 \pm 1.02}$ & $\underset{\mathrm{ab}}{82.37 \pm 1.53^{\mathrm{B}}}$ \\
\hline 28 & $\underset{B, n s}{76.88 \pm 6.47}$ & $\underset{, a}{82.81 \pm 4.98^{A B}}$ & $\begin{array}{c}84.89 \pm 6.96 \\
A B, n s\end{array}$ & $\begin{array}{c}96.83 \pm 0.57 \\
\mathrm{~A}, \mathrm{a}\end{array}$ & $\underset{, a}{79.90 \pm 0.73^{A B}}$ & $\begin{array}{c}85.18 \pm 2.32 \\
A B, a\end{array}$ & $\underset{, a}{86.28 \pm 2.97^{A B}}$ \\
\hline
\end{tabular}

MSGF: with whole meal obtained from wheat harvested at milky stage, DSGF: with whole meal obtained from wheat harvested at dough stage. Statistically differences were shown different letters $(P<0.05)$.

NS: not statistically significant. A-BThe significant differences between the samples were expressed in capital letters, a-bThe significant differences between storage times were expressed in lower case letters.

In previous study, Joung, Lee [63] stated that the use of phenolic acids such as ferulic and coumaric acid by microorganisms leads to the formation of different phenolic components such as vanillic and $p$ hydroxybenzoic acid during microbial growth and after the acidification period. Furthermore, the breakdown of milk proteins such as casein (i.e. which contain amino acids, such as tyrosine, which have a phenolic side chain) by yoghurt bacteria causes an increase in the total phenolic content of yoghurts [64].

\section{S. thermophilus and L. delbrueckii ssp. bulgaricus counts of yoghurt samples}

$S$. thermophilus and L. delbrueckii ssp. bulgaricus counts of yoghurt samples are shown in Table 6 . In yoghurt samples with MSGF and DSGF the average counts of $S$. thermophilus were detected between 5.93$6.42 \mathrm{log} \mathrm{cfu} / \mathrm{mL}$ during cold storage period. There were no significant differences $(P>0.05)$ in the counts of $S$. thermophilus among all yoghurt samples, and the viable counts showed a slight reduction during the 28 days of refrigerated storage. These results are in agreement with Delgado-Fernández, Corzo [65] who reported that the addition of FOS into yoghurt had no effects on the growth of yoghurt starter cultures. The 
lowest viable counts were determined at the end of the storage time. Significant differences in the number of $S$. thermophilus were seen only on the 14th day of the storage. It was observed that the $2 \%$ addition ratio with MSGF and DSGF slightly supported the development of $S$. thermophilus on day 14 of storage. Similar results were reported by Akalın, Fenderya [46] and Akalın, Gönç [37].

During 28 days of the storage period, the average counts of $L$. delbrueckii ssp. bulgaricus in control, $1 \%$ MSGF, 2\% MSGF, 3\% MSGF, 1\% DSGF, 2\% DSGF and 3\% DSGF samples were defined to be 7.47, 7.55, 7.62, 7.62, 7.52, 7.57 and $7.34 \mathrm{log} \mathrm{cfu} / \mathrm{mL}$, respectively. The lowest viable count of L. delbrueckii ssp. bulgaricus was observed in yoghurt sample with 3\% DSGF. This result may be explained by the levels of starch in DSGF, since starch decreases water activity of yoghurt samples and the metabolism of $L$. delbrueckii ssp. bulgaricus may have been inhibited $[36,66]$. It was previously reported that IWG had less digestible starch and more fiber content than mature wheat grains [10]. The viability of L. delbrueckii ssp. bulgaricus in yoghurt samples was higher when they were grown in the presence of MSGF at the end of the storage period (Table 6).

Table 6. S. thermophilus and L. delbrueckii ssp. bulgaricus (log cfu/mL) counts of yoghurts during the storage time.

\begin{tabular}{|c|c|c|c|c|c|c|c|}
\hline \multirow{2}{*}{$\begin{array}{l}\text { Storage times } \\
\text { (day) }\end{array}$} & \multicolumn{7}{|c|}{ Sample } \\
\hline & Control & $\begin{array}{c}1 \% \\
\text { MSGF }\end{array}$ & $2 \%$ MSGF & $3 \%$ MSGF & $1 \%$ DSGF & $2 \%$ DSGF & $3 \%$ DSGF \\
\hline \multicolumn{8}{|l|}{ S. thermophilus } \\
\hline 1 & $\begin{array}{c}6.56 \pm 0.12 \\
\mathrm{NS}, \mathrm{a}\end{array}$ & $\begin{array}{c}6.68 \pm 0.09 \\
\text { NS,a }\end{array}$ & $\underset{\mathrm{NS}, \mathrm{a}}{6.81 \pm 0.04}$ & $\underset{, a}{6.76 \pm 0.08^{\mathrm{NS}}}$ & $\underset{\mathrm{a}}{6.61 \pm 0.14 \mathrm{NS}}$ & $\begin{array}{c}6.77 \pm 0.08^{N} \\
S, a\end{array}$ & $\underset{\mathrm{S}, \mathrm{a}}{6.72 \pm 0.09^{\mathrm{N}}}$ \\
\hline 7 & $\begin{array}{c}6.51 \pm 0.11 \\
\mathrm{NS}, \mathrm{a}\end{array}$ & $\begin{array}{c}6.66 \pm 0.08 \\
N S, a\end{array}$ & $\begin{array}{c}6.76 \pm 0.06 \\
N S, a\end{array}$ & $\underset{, a}{6.70 \pm 0.11^{\mathrm{NS}}}$ & $\underset{a}{6.56 \pm 0.15^{N S}}$ & $\underset{s, a}{6.67 \pm 0.06^{N}}$ & $\underset{s, a}{6.65 \pm 0.08^{N}}$ \\
\hline 14 & $\underset{\mathrm{B}, \mathrm{a}}{6.41 \pm 0.04}$ & $\underset{\mathrm{B}, \mathrm{a}}{6.46 \pm 0.03}$ & $\underset{A, a}{6.63 \pm 0.03}$ & $\underset{\mathrm{a}}{6.59 \pm 0.02^{\mathrm{A}}}$ & $6.42 \pm 0.00^{\mathrm{B}, \mathrm{a}}$ & $\underset{a}{6.59 \pm 0.01^{\mathrm{A}}}$ & $\underset{\mathrm{a}}{6.47 \pm 0.02^{\mathrm{B}}}$ \\
\hline 21 & $\begin{array}{c}5.11 \pm 0.06 \\
N S, b\end{array}$ & $\underset{N S, b}{5.41 \pm 0.04}$ & $\begin{array}{c}5.48 \pm 0.04 \\
N S, b\end{array}$ & $\underset{, b}{5.36 \pm 0.17^{\mathrm{NS}}}$ & $\underset{b}{5.23 \pm 0.10^{N S}}$ & $\underset{\mathrm{s}, \mathrm{b}}{5.39 \pm 0.13^{\mathrm{N}}}$ & $\underset{S, a}{5.30 \pm 0.16^{N}}$ \\
\hline 28 & $\begin{array}{c}5.06 \pm 0.12 \\
N S, b\end{array}$ & $\underset{N S, b}{5.23 \pm 0.07}$ & $\begin{array}{c}5.46 \pm 0.05 \\
N S, b\end{array}$ & $\underset{, b}{5.31 \pm 0.23^{N S}}$ & $\underset{\mathrm{b}}{5.11 \pm 0.13^{\mathrm{NS}}}$ & $\underset{\mathrm{S}, \mathrm{b}}{5.21 \pm 0.11^{\mathrm{N}}}$ & $\underset{\mathrm{S}, \mathrm{a}}{5.06 \pm 0.14^{\mathrm{N}}}$ \\
\hline \multicolumn{8}{|l|}{$\begin{array}{l}\text { L. delbrueckii } \\
\text { ssp. bulgaricus }\end{array}$} \\
\hline 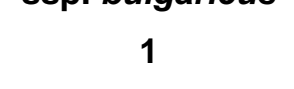 & $\begin{array}{c}8.58 \pm 0.04 \\
A B, a\end{array}$ & $\begin{array}{c}8.63 \pm 0.05 \\
A, a\end{array}$ & $\underset{\mathrm{A}, \mathrm{a}}{8.65 \pm 0.06}$ & $\underset{a}{8.73 \pm 0.04^{A}}$ & $\underset{a}{8.663 \pm 0.04 A}$ & $\underset{a}{8.66 \pm 0.04 \mathrm{~A}}$ & $\underset{a}{8.39 \pm 0.10^{B},}$ \\
\hline 7 & $\begin{array}{c}8.51 \pm 0.03 \\
N S, a\end{array}$ & $\begin{array}{c}8.53 \pm 0.01 \\
N S, a\end{array}$ & $\begin{array}{c}8.63 \pm 0.07 \\
N S, a\end{array}$ & $\underset{, a}{8.67 \pm 0.07 \mathrm{NS}}$ & $\underset{a}{8.57 \pm 0.02^{N S}}$ & $\underset{\mathrm{S}, \mathrm{a}}{8.60 \pm 0.04^{\mathrm{N}}}$ & $\underset{S, a}{8.42 \pm 0.16^{N}}$ \\
\hline 14 & $\begin{array}{c}7.48 \pm 0.01 \\
\mathrm{~A}, \mathrm{~b}\end{array}$ & $\begin{array}{c}7.52 \pm 0.01 \\
\mathrm{~A}, \mathrm{~b}\end{array}$ & $\begin{array}{c}7.60 \pm 0.01 \\
A, b\end{array}$ & $\underset{\mathrm{b}}{7.60 \pm 0.06^{\mathrm{A}}}$ & $7.50 \pm 0.01^{\mathrm{A}, \mathrm{b}}$ & $\underset{b}{7.53 \pm 0.05^{A}}$ & $\underset{\mathrm{b}}{7.32 \pm 0.05^{\mathrm{B}},}$ \\
\hline 21 & $\underset{N S, C}{6.72 \pm 0.32}$ & $\begin{array}{c}6.79 \pm 0.29 \\
N S, C\end{array}$ & $\underset{N S, C}{6.89 \pm 0.28}$ & $\underset{, \mathrm{C}}{6.79 \pm 0.13^{\mathrm{NS}}}$ & 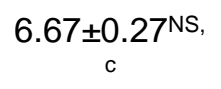 & $\underset{S, c}{6.76 \pm 0.36^{N}}$ & $\underset{c}{6.50 \pm 0.2^{\mathrm{NS}}}$ \\
\hline 28 & $\underset{\mathrm{C}, \mathrm{d}}{6.06 \pm 0.01}$ & $\underset{A, C}{6.27 \pm 0.03}$ & $\underset{A, d}{6.33 \pm 0.02}$ & $6.29 \pm 0.01^{A}$ & $\underset{c}{6.22 \pm 0.06^{A B},}$ & $\underset{c}{6.31 \pm 0.03^{A},}$ & $6.09 \pm 0.06^{B}$ \\
\hline
\end{tabular}

MSGF: with whole meal obtained from wheat harvested at milky stage, DSGF: with whole meal obtained from wheat harvested at dough stage. Statistically differences were shown different letters $(P<0.05)$.

NS: not statistically significant. A-BThe significant differences between the samples were expressed in capital letters, ${ }^{a-}$ bThe significant differences between storage times were expressed in lower case letters.

The MSGF (4.37 g/100g) contained higher fructan content than the DSGF (3.76 g/100g). IWG is an innovative raw material as a natural fructans source. In wheat kernels, fructans are accumulated at a higher level 2-3 weeks after flowering, thereafter their content rapidly decreases [67]. Similarly, our data are in agreement with Akalın, Gönç [37] who reported that FOS addition in reduced-fat probiotic yoghurts supported both $S$. thermophilus and L. delbrueckii ssp. bulgaricus numbers. Additionally, fungi and yeast were detected at a level of $<1 \log$ cfu $/ \mathrm{mL}$ in all yoghurts by the 28 th day of storage. 


\section{Sensory properties of yoghurt samples}

The scores for sensory properties of yoghurt samples are given in Table 7. The supplementation of yoghurt with MSGF and DSGF had a significant effect $(p<0.05)$ on all the sensory parameters. The appearance score decreased with increasing enrichment rate of MSGF and DSGF, also the yoghurt with DSGF had lower appearance score than MSGF. Control and MSGF 3\% samples gained the most appreciation by the panelists in terms of texture evaluation. The taste and odor scores of yoghurt samples decreased significantly $(p<0.05)$ with the increasing addition rates of MSGF and DSGF. The yoghurts containing 3\% MSGF and DSGF, had the lowest admiration by panelists with regard to taste and odor evaluations. This result may be attributed to IWG provided cereal odor and taste into yoghurts. Similar results were reported by Terpou, Bekatorou [7] and Hoppert, Zahn [68].

Table 7. Sensory properties of yoghurts at the 14th day of refrigerated storage.

\begin{tabular}{llllll}
\hline Samples & Appearance & Texture & Mouth feel & Odor & Taste \\
\hline Control & $4.88 \pm 0.03^{\mathrm{a}}$ & $4.82 \pm 0.11^{\mathrm{a}}$ & $4.38 \pm 0.07^{\mathrm{ab}}$ & $4.96 \pm 0.06^{\mathrm{a}}$ & $4.82 \pm 0.08^{\mathrm{a}}$ \\
$\mathbf{1} \%$ MSGF & $3.65 \pm 0.21^{\mathrm{ab}}$ & $3.65 \pm 0.21^{\mathrm{b}}$ & $3.78 \pm 0.04^{\mathrm{bc}}$ & $4.30 \pm 0.42^{\mathrm{ab}}$ & $4.35 \pm 0.21^{\mathrm{ab}}$ \\
$\mathbf{2} \%$ MSGF & $4.43 \pm 0.25^{\mathrm{ab}}$ & $4.55 \pm 0.07^{\mathrm{ab}}$ & $4.55 \pm 0.07^{\mathrm{ab}}$ & $3.68 \pm 0.11^{\mathrm{bc}}$ & $4.03 \pm 0.31^{\mathrm{abc}}$ \\
$\mathbf{3} \%$ MSGF & $4.40 \pm 0.85^{\mathrm{ab}}$ & $4.70 \pm 0.42^{\mathrm{a}}$ & $4.80 \pm 0.28^{\mathrm{a}}$ & $3.80 \pm 0.28^{\mathrm{bc}}$ & $3.80 \pm 0.28^{\mathrm{bc}}$ \\
$\mathbf{1 \%}$ DSGF & $3.90 \pm 0.14^{\mathrm{ab}}$ & $3.98 \pm 0.32^{\mathrm{ab}}$ & $4.33 \pm 0.11^{\mathrm{ab}}$ & $4.18 \pm 0.11^{\mathrm{abc}}$ & $4.58 \pm 0.25^{\mathrm{ab}}$ \\
$\mathbf{2} \%$ DSGF & $2.97 \pm 0.32^{\mathrm{b}}$ & $3.97 \pm 0.32^{\mathrm{ab}}$ & $3.08 \pm 0.46^{\mathrm{c}}$ & $3.35 \pm 0.21^{\mathrm{bc}}$ & $3.30 \pm 0.28^{\mathrm{cd}}$ \\
$\mathbf{3} \%$ DSGF & $3.20 \pm 0.28^{\mathrm{b}}$ & $3.55 \pm 0.07^{\mathrm{b}}$ & $3.10 \pm 0.14^{\mathrm{c}}$ & $3.25 \pm 0.35^{\mathrm{c}}$ & $2.83 \pm 0.11^{\mathrm{d}}$ \\
\hline
\end{tabular}

MSGF: with whole meal obtained from wheat harvested at milky stage, DSGF: with whole meal obtained from wheat harvested at dough stage. Statistically differences were shown different letters $(P<0.05)$.

\section{CONCLUSIONS}

In this study, physical, chemical, nutritional, textural, microbiological and sensorial properties of yoghurt samples enriched with MSGF and DSGF were determined. The results showed that enrichment of immature wheat flour in yoghurt samples increased the nutritional value of yoghurts, due to increasing protein and mineral content, total phenolic compounds, antioxidant activity and fructan content. Phytic acid content of the yoghurt samples with MSGF and DSGF were reduced significantly by residual activity of the starter cultures. On the other hand, the addition of MSGF and DSGF to yoghurts demonstrated a positive effect on firmness, consistency, and water holding capacity. In yoghurt samples with MSGF, S. thermophilus and L. delbrueckii ssp. bulgaricus counts were higher than yoghurt with DSGF because there was a higher fructan content in MSGF than DSGF. The sensory evaluation showed that enrichment with MSGF and DSGF provided cereal flavor to yoghurt samples. For this reason, consumer acceptance decreased with increasing concentration of MSGF and DSGF additives in yoghurt samples. Consequently, MSGF and DSGF seems to be good alternative supplement for improving textural and nutritional properties of yoghurts. MSGF and DSGF can be used in combination with a total of $3 \%$ for obtaining an excellent effect on textural and nutritional attributes of yoghurts. Further studies can also be performed by flavoring agents to optimize sensorial characteristics of yoghurts.

Acknowledgement: This experimental data was obtained from doctoral dissertation and it was supported by Selcuk University Scientific Research Projects Coordinatorship (Grant number, 14101005).

Conflicts of Interest: The authors declare no conflict of interest.

\section{REFERENCES}

1. Serafeimidou A, Zlatanos S, Laskaridis K,Sagredos A. Chemical characteristics, fatty acid composition and conjugated linoleic acid (CLA) content of traditional Greek yogurts. Food Chem. 2012;134:1839-46.

2. Hashim IB, Khalil AH,Afifi HS. Quality characteristics and consumer acceptance of yogurt fortified with date fibre. J Dairy Sci. 2009;92(11):5403-7.

3. Zare F, Champagne CP, Simpson B.K., Orsat V,Boye Jl. Effect of the addition of pulse ingredients to milk on acid production by probiotic and yoghurt starter cultures. Food Sci Technol Int. 2012;45:155-60.

4. Bertolino M, Belviso S, Dal Bello B, Ghirardello D, Giordano M, Rolle L, et al. Influence of the addition of different hazelnut skins on the physicochemical, antioxidant, polyphenol and sensory properties of yogurt. Lwt-Food Sci Technol. 2015;63(2):1145-54. 
5. Sah BNP, Vasiljevic T, McKechnie S,Donkor ON. Physicochemical, textural and rheological properties of probiotic yogurt fortified with fibre-rich pineapple peel powder during refrigerated storage. Lwt-Food Sci Technol. 2016;65:978-86.

6. Tomic N, Dojnov B, Miocinovic J, Tomasevic I, Smigic N, Djekic I, et al. Enrichment of yoghurt with insoluble dietary fiber from triticale - A sensory perspective. Lwt-Food Sci Technol. 2017;80:59-66.

7. Terpou A, Bekatorou A, Kanellaki M, Koutinas AA,Nigam P. Enhanced probiotic viability and aromatic profile of yogurts produced using wheat bran (Triticum aestivum) as cell immobilization carrier. Process Biochem. 2017;55:110.

8. Franck A. Technological functionality of inulin and oligofructose. Brit J Nutr. 2002;87:287-91.

9. Cimini S, Locato V, Vergauwen R, Paradiso A, Cecchini C, Vandenpoel L, et al. Fructan biosynthesis and degradation as part of plant metabolism controlling sugar fluxes during durum wheat kernel maturation. Front Plant Sci. 2015;6(89).

10. Casiraghi MC, Pagani MA, Erba D, Marti A, Cecchini C,D'egidio MG. Quality and nutritional properties of pasta products enriched with immature wheat grain. Int J Food Sci Nutr. 2013;64(5):631-7.

11. Mujoo R,Ng PKW. Physicochemical properties of bread baked from flour blended with immature wheat meal rich in fructooligosaccharides. J Food Sci. 2003;68:2448-52.

12. Paradiso A, Cecchini C, De Gara L,D'Egidio MG. Functional, antioxidant and rheological properties of meal from immature durum wheat. J Cereal Sci. 2006;43(2):216-22.

13. Pepe O, Ventorino V, Cavella S, Fagnano M,Brugno R. Prebiotic content of bread prepared with flour from immature wheat grain and selected dextran-producing lactic acid bacteria. Appl Environ Microb. 2013;79(12):3779-85.

14. Casiraghi MC, Zanchi R, Canzi E, Pagani MA, Benini TVL,D'Egidio MG. Prebiotic potential and gastrointestinal effects of immature wheat grain (IWG) biscuits. Antonie Leeuwenhoek. 2011;99:795-805.

15. Aktaş K, Demirci T,Akin N. Chemical composition and microbiological properties of tarhana enriched with immature wheat grain. J Food Process Pres. 2015;39(6):3014-21.

16. AOAC. Official Methods of Analysis, 16th ed. Association of Official Analytical Chemists. 1998.

17. AOAC. Official Methods of Analysis. in Fat content and raw and pasteurized whole milk gerber method by weight (method I). 2002.

18. Skujins S. Handbook for ICP - AES (Vartian-Vista). A Short Guide To Vista Series ICP - AES Operation. Variant Int. AG, Zug, version 1.0, Switzerland. 1998.

19. McLellan MR, Lind R, Kime RW. Hue angle determinations and statistical analysis for multiquandrant hunter $L, a, b$ data J Food Qual. 1995;18(3): 235-40.

20. Agil R, Gaget A, Gliwa J, Avis TJ, Willmore WG,Hosseinian F. Lentils enhance probiotic growth in yogurt and provide added benefit of antioxidant protection. Lwt- Food Sci Technol. 2013;50(1):45-9.

21. Ye M, Ren L, Wu Y, Wang Y, Liu Y. Quality characterictics and antioxsidant activity of hickory-black soybean yogurt. Food Sci Technol Int. 2013;51:314-8.

22. Haug W, Lantzsch HJ. Sensitive method for the rapid determination of phytate in cereals and cereal product. J Sci Food Agr. 1983;34:1423-6.

23. Prosky L, Hoebregs H. Methods to determine food inulin and oligofructose. J Nutr. 1999;129:1418-23.

24. AACC. Approved methods of the American Association of Cereal Chemists. in Fructans in foods and food productsion exchange chromatographic method. 2001: St.Paul.

25. Öztürk Hİ, Aydın S, Sözeri D, Demirci T, Sert D,Akın N. Fortification of set-type yoghurts with Elaeagnus angustifolia L. flours: Effects on physicochemical, textural, and microstructural characteristics. Lwt-Food Sci Technol. 2018;90:620-6.

26. Brand-Williams W, Cuvelier ME,Berset C. Use of free radical method to evaluate antioxidant activity. Lebensm Wiss Technol. 1995;28:25-30.

27. Re R, Pellegrını N, Proteggente A, Pannala A, Yang M,Rıce-Evans C. Antioxidant activity applying an improved ABTS radical cation decolorization assay. Free Radic Biol Med. 1999;26(9):1231-7.

28. McCue P,Shetty K. Role of carbohydrate-cleaving enzymes in phenolic antioxidant mobilization from whole soybean fermented with Rhizopus oligosporus. Food Biothecnol. 2003;17:27-37.

29. Anonymous. Yoghurt: Enumeration of characteristic microorganisms-Colony count technique at 37 degrees. FILIDF Standard, vol. 117B, 4p. 1997: Brussels, Belgium: International Dairy Federation.

30. Richardson G. Standard methods of the examination of dairy products. American Public Health Association: Port City Press, Inc., Baltimore, MD. 1985.

31. Tamime AY, Barrantes E,Sword AM. The effect of starch based fat substitutes on the microstructure of set-style yogurt made from reconstituted skimmed milk powder. Int J Dairy Technol. 1996;49(1):1-10.

32. Minitab C. Minitab reference manual (Release 7.1). State Coll., PA16801, USA. 1991. 
33. Levent $\mathrm{H}$,Bilgiçli $\mathrm{N}$. Effects of immature wheat on the nutritional and antinutritional quality of leavened and unleavened bread. Qual Assur Saf Crop. 2016;8(4):583-91.

34. Katagiri M, Masuda T, Tani F,Kitabatake N. Expression and Development of Wheat Proteins during Maturation of Wheat Kernel and the Rheological Properties of Dough Prepared from the Flour of Mature and Immature Wheat. Food Sci Technol Res. 2011;17(2):111-20.

35. Ramirez-Santiago C, Ramos-Solis L, Lobato-Calleros C, Peña-Valdivia C, Vernon-Carter EJ, Alvarez-Ramírez J. Enrichment of stirred yogurt with soluble dietary fiber from Pachyrhizus erosus L. Urban: Effect on syneresis, microstructure and rheological properties. J Food Eng. 2010;101:229-35.

36. Aportela-Palacios A, Sosa-Morales ME,Vélez-Ruiz JF. Rheological and physicochemical behavior of fortified yogurt, with fiber and calcium J Texture Stud. 2005;36:333-49.

37. Akalın AS, Gönç S, Ünal G,Fenderya S. Effects of fructooligosaccharide and whey protein concentrate on the viability of starter culture in reduced-fat probiotic yogurt during storage. J Food Sci. 2007;72(7):222-7.

38. Cimini S, Locato V, Vergauwen R, Paradiso A, Cecchini C, Vandenpoel L, et al. Fructan biosynthesis and degradation as part of plant metabolism controlling sugar fluxes during durum wheat kernel maturation. Front Plant Sci. 2015;6(89):1-10.

39. Kaur M, Oberoi DPS, Sogi DS,Gill BS. Physicochemical, morphological and pasting properties of acid treated starches from different botanical sources. J Food Sci Technol. 2011;48(4):460-5.

40. Kalab M, Allan-Wojtas P,Phipps-Todd BE. Development of microstructure in set-style nonfat yoghurt - A review. Food Microstruct. 1983;2:51-66.

41. Crispín-Isidro G, Lobato-Calleros C, Espinosa-Andrews H, Alvarez-Ramirez J,Vernon-Carter EJ. Effect of inulin and agave fructans addition on the rheological, microstructural and sensory properties of reduced-fat stirred yogurt. Lwt-Food Sci Technol. 2015;62(1, Part 2):438-44.

42. Oraç A,Akın N. How do different cooling temperatures affect the characteristics of set-type yoghurt gel? Int Dairy J. 2019;97:49-56.

43. Donkor ON, Henriksson A, Vasiljevic T,Shah NP. Effect of acidification on the activity of probiotics in yoghurt during cold storage. Int Dairy J. 2006;16(10):1181-9.

44. Bilgiçli N,ibanoğlu Ş. Effect of wheat germ and wheat bran on the fermentation activity, phytic acid content and colour of tarhana, a wheat flour-yoghurt mixture. J Food Eng. 2007;78(2):681-6.

45. Corradini C, Bianchi F, Matteuzzi D, Amoretti A, Rossi M,Zanoni S. High-performance anion-exchange chromatography coupled with pulsed amperometric detection and capillary zone electrophoresis with indirect ultra violet detection as powerful tools to evaluate prebiotic properties of fructooligosaccharides and inulin. $\mathrm{J}$ Chromatogr A. 2004;1054(1):165-73.

46. Akalın AS, Fenderya S,Akbulut N. Viability and activity of bifidobacteria in yoghurtcontaining fructooligosaccharide during refrigerated storage. Int J Food Sci Technol. 2004;39:613-21.

47. Wang $X$, Kristo E,LaPointe G. The effect of apple pomace on the texture, rheology and microstructure of set type yogurt. Food Hydrocoll. 2019;91:83-91.

48. Costa MP, Frasao BS, Silva ACO, Freitas MQ, Franco RM,Conte-Junior CA. Cupuassu (Theobroma grandiflorum) pulp, probiotic, and prebiotic: Influence on color, apparent viscosity, and texture of goat milk yogurts. J Dairy Sci. 2015;98(9):5995-6003.

49. Izadi Z, Nasirpour A, Garoosi GA,Tamjidi F. Rheological and physical properties of yogurt enriched with phytosterol during storage. J Food Sci Technol. 2015;52(8):5341-6.

50. Iametti S, Bonomi F, Pagani MA, Zardi M, Cecchini C,D'Egidio MG. Properties of the protein and carbohydrate fractions in immature wheat kernels. J Agr Food Chem. 2006;54:10239-44.

51. do Espírito Santo AP, Perego P, Converti A,Oliveira MN. Influence of milk type and addition of passion fruit peel powder on fermentation kinetics, texture profile and bacterial viability in probiotic yoghurts. Lwt-Food Sci Technol. 2012;47(2):393-9.

52. Srisuvor N, Chinprahast N, Prakitchaiwattana C,Subhimaros S. Effects of inulin and polydextrose on physicochemical and sensory properties of low-fat set yoghurt with probiotic-cultured banana purée. Food Sci Technol Int. 2013;51:30-6.

53. Sert D, Mercan E,Dertli E. Characterization of lactic acid bacteria from yogurt-like product fermented with pine cone and determination of their role on physicochemical, textural and microbiological properties of product. Lwt-Food Sci Technol. 2017;78:70-6.

54. Mohamed A, Zayan AF,Shahein N. Physiochemical and sensory evaluation of yoghurt fortified with dietary fiber and phenolic compounds. Life Sci J. 2014;11(9):816-22.

55. Mousavi M, Heshmati A, Daraei Garmakhany A, Vahidinia A,Taheri M. Texture and sensory characterization of functional yogurt supplemented with flaxseed during cold storage. Food Sci Nutr. 2019;7(3):907-17. 
56. Kycia K, Chlebowska-Śmigiel A, Gniewosz M,Sokół E. Effect of pullulan on the physicochemical properties of yoghurt. Int J Dairy Technol. 2018;71(1):64-70.

57. Rudra SG, Nath P, Kaur C,Basu S. Rheological, storage stability and sensory profiling of low-fat yoghurt fortified with red capsicum carotenoids and inulin. J Food Process Pres. 2017;41(4):e13067.

58. Kim JK,Kim SK. Antioxidant and antiproliferative activities in immature and mature wheat kernels. Food Chem. 2016;196:638-45.

59. Yang D, Shin JA, Gan LJ, Zhu XM, Hong ST, Sung CK, et al. Comparison of nutritional compounds in premature green and mature yellow whole wheat in Korea. Cereal Chem. 2012;89(6):284-9.

60. Merendino N, D'Aquino M, Molinaria R, De Gara L, D'Egidio MG, Paradiso A, et al. Chemical characterization and biological effects of immature durum wheat in rats. J Cereal Sci. 2006;43(2):129-36.

61. Yıldız G, Vatan Ö, Çelikler S,Dere S. Determination of the phenolic compounds and antioxidative capacity in red algae Gracilaria bursa-pastoris. Int J Food Prop. 2009;14:496-502.

62. Yüksel Z, Avcı E,Erdem YK. Characterization of binding interactions between green tea flavanoids and milk proteins. Food Chem. 2010;121:450-6.

63. Joung JY, Lee JY, Ha YS, Shin YK, Kim Y, Kim SH, et al. Enhanced microbial, functional and sensory properties of herbal yogurt fermented with Korean traditional plant extracts. Korean J Food Sci An. 2016;36(1):90-9.

64. Shah NP. Effects of milk-derived bioactives: an overview. Brit J Nutr. 2000;84:3-10.

65. Delgado-Fernández P, Corzo N, Olano A, Hernández-Hernández O,Moreno FJ. Effect of selected prebiotics on the growth of lactic acid bacteria and physicochemical properties of yoghurts. Int Dairy J. 2019;89:77-85.

66. Shah NP,Ravula RR. Influence of water activity on fermentation, organic acids production and viability of yogurt and probiotic bacteria. Aust J Dairy Technol. 2000;55(3):127.

67. D'Egidio MG, Cecchini C, Corradini C, Donini V, Pignatelli V,Cervigni T, Cereals Novel uses and processes. Utilisation of immature durum wheat. Innovative uses of cereals for fructose production, ed. G.M. Campbell, C. Webb, and S. McKee. 1997, New York: Plenum Press.

68. Hoppert K, Zahn S, Jänecke L, Mai R, Hoffmann S,Rohm H. Consumer acceptance of regular and reduced-sugar yogurt enriched with different types of dietary fiber. Int Dairy J. 2013;28(1):1-7.

(C) 2021 by the authors. Submitted for possible open access publication under the terms and conditions of the Creative Commons Attribution (CC BY NC) license (https://creativecommons.org/licenses/by-nc/4.0/). 